\title{
4 Growing under the shadow of oil
}

\section{Institutionalizing the mining sector in Ecuador between 2002 and 2019}

\author{
Paúl Cisneros
}

\section{Introduction}

There is now considerable evidence that under certain conditions, petroleum tends to produce adverse effects on the economic, social, and political wellbeing of a country (Ross, 2015). One particular area of concern for scholars and practitioners relates to how oil dependence influences the capacity of a state to promote economic development through competitive diversification, that is, the creation of competitive advantages in other non-extractive sectors (Auty, 1993; Gylfason, 2006). Existing research overlooks how oil dependence affects the development of institutions in other extractive sectors such as metal mining (gold, copper, zinc, among others) or gas. This chapter studies how oil dependence affected the development of the metals mining sector in Ecuador between 2002 and 2019. The interest in this issue arises from the cases of Colombia and Ecuador, where governments have unsuccessfully tried to develop the metal mining sector with the expectation of replacing oil as the primary source of state revenues, and of launching more extensive economic diversification plans (Ponce Muriel, 2012; Cisneros, 2017).

Some scholars argue that high dependence on the extraction of natural resources creates conditions that allow for and encourage the continued expansion of the extractive sector. They call this the extractive imperative (Arsel et al., 2016a). Environment and development policies are thought to reinforce extractive activities deepening and speeding up the extraction of value from nature and natural resources (Arsel et al., 2016b).

The extractive imperative thesis appears sound when extractive sectors, such as hydrocarbons, metals, or gas, are analyzed separately. The development of metal mining in Peru is a case that conforms with the extractive imperative thesis. The expansion of large-scale mining in the past two decades prompted the development of institutions that reinforce its importance for the economic development of the country (Orihuela \& Paredes, 2017). However, the original formulation of the extractive imperative thesis fails to explain why, despite the important role of the oil sector in the economy and the support given to metals mining in their development plans, Colombia and Ecuador have dramatically failed to achieve their goals in the mining sector. 
The argument put forward in this chapter is that economic dependence on the oil sector undermines some conditions necessary for the development of the metal mining sector. Specifically, the selection of appropriate policy instruments to deal with the specific needs mining. While the extractive imperative thesis only considers positive or reinforcing feedbacks between extractive sectors, this chapter studies negative feedbacks to offer a more nuanced understanding of the processes of institutional development in the extractive sector.

The main questions in this chapter are: Why did plans to develop the mining sector fail in the past decade and a half? What role does oil dependence play in the production of this outcome? The study focuses on the process of developing the capacity to promote, establish, and develop large-scale metal mining operations according to long-term plans, and with support from key actors.

The next two sections, present the background information on the case and develop the theoretical approach that underpins the empirical study. The following two sections present the methods and the results of the study. The concluding remarks brings the chapter to a close.

\section{The case}

In 2006, Rafael Correa was elected president of Ecuador with a political agenda that proposed to bring the state back to the center of public action. This plan included the direct participation of public sector organizations in oil and metal mining. During his campaign, Correa announced the use of the endowment of nonfuel mineral resources - mostly gold and copper - to close the expanding wealth gap, especially in the regions where extractive activities were taking place. The main objective of the proposed policy change was to take advantage of the unusually high commodity prices that started in 2003 by increasing state revenues received from this sector. Developing a strong metal mining sector became one of the government's top priorities. According to the government's plans, the metal mining sector had to grow quickly, and the most advanced large-scale mining projects (Mirador and Fruta del Norte) were to yield royalties as soon as 2012 and become the primary source of state revenue by 2020 .

However, by late 2018, investments in the metal mining sector only contributed to $1.61 \%$ of the GDP. It had indeed surpassed the $0.05 \%$ threshold of the 2001 and 2007 period (Ministerio de Energía y Minas, 2007, p. 11), but its contribution to the economy is still small. Authorities now expect that metal mining will amount to 4\% of GDP by 2021. Important challenges remain to achieve this goal as critical components of the sector are still largely underdeveloped. The government has kept the mining cadastre closed to new concessions and suppressed the sectoral ministry in 2018, and several strategic projects are facing local consultations seeking to ban mining in their jurisdictions. In short, the development of the metal mining sector has fallen short of the expectations set by the reformist agenda launched in 2006 .

The Ecuadorean experience under the government of Rafael Correa fits the description of the extractive imperative developed by Arsel et al. (2016a, 
2016b). The government of Rafael Correa was elected with the support of a large majority that increased as the government expanded social programs and other forms of public investments. The state recovered a central position in the extractive industries and pushed for their expansion despite opposition from former allies such as the indigenous movement and other progressive actors. Despite these characteristics, the extractive imperative in Ecuador did accelerate the expansion of the mining sector.

\section{Theoretical background}

States are organized into policy sectors to manage a wide array of public problems at the same time (Baumgartner \& Jones, 1991). In the realm of the extractive industries, it is quite common to find separate ministries to deal with nonfuel minerals and hydrocarbons. This division of labor across the public sector produces the development of specialized means to deal with the particular challenges of each sector. However, during their interventions across policy sectors, actors carry ideas about how sectoral development should take place. Ideas operate as institutions because they constrain and shape the agency of policy actors (Lascoumes \& Le Gales, 2007) by defining what is appropriate to tackle problems in specific contexts.

There are two general types of policy ideas. First, ideas may refer to principles that define how the world ought to be. Some of these ideas function as paradigms; therefore, they are hard to change via policy-oriented learning and usually require a shock to be overturned (Nohrstedt, 2005). An example of this type of idea is the role attributed to the state in the development of the extractive sectors. Two rival paradigms persist in this regard. The market-oriented paradigm limits the role of the state to set the conditions for private companies to operate. The statist paradigm promotes active and direct involvement of public sector organizations in the extractive activities.

The second type of policy ideas is more instrumental and defines how actors should translate principles into action. They also function as institutions because they incorporate notions of what is appropriate to address the problems faced by target populations, such as the use of direct coercion versus the use of informative instruments to change an actor's behavior (Howlett \& Cashore, 2009; Schneider \& Ingram, 1990; Weible \& Sabatier, 2009).

While policy instruments may be part of a developed belief system (Radae1li, 1995), they may also be discrete ideational elements that work as cognitive shortcuts adopted from other contexts (Weyland, 2006). Often, policy actors import designs from other contexts for reasons alien to the outcomes produced by such policies. Additionally, they often fail to adapt these designs to the specific characteristics of the problem at hand (Mukhtarov \& Daniell, 2016).

Given that the oil sector has dominated the Ecuadorian economy since the 1970s, it is expected that some policy ideas will constrain the selection of instruments in other sectors. Specifically, it is expected that some policy goals and instruments used in the oil sector interfered with the development of the metal 
mining sector, reducing the capacity to achieve the objectives set for the latter. The chapter assesses how objectives and tools from the oil sector influenced the political, economic, and administrative dimensions of the metal mining sector.

Working towards alignment of the political, economic, and administrative dimensions is crucial during cycles of economic expansion caused by high commodity prices in the international markets (Auty, 1993). In the political dimension, governments need to mobilize support from political and economic elites to expand and consolidate the extractive sectors. Recent studies on national political settlements highlight the importance of elite cohesion to pursue institutional development in the extractive sectors or manage the political spaces where organized civil society challenges their development (Bebbington et al., 2018, 2019).

Developing a metal mining sector requires setting economic conditions through the use of policy instruments both at the sectoral level and at the local level where companies operate. The sectoral level demands designing a flow of resources that allows companies to recover their investments and make a profit. Additionally, it requires the development of competitive advantages that help mining investments increase the production of public value (Mayorga Alba, 2009; Arzeki et al., 2011). Cheap electricity and reliable infrastructure are some elements that offer competitive advantages. Setting economic conditions at the local level means developing mechanisms to allocate benefits from mining operations to local communities to reduce the likelihood of conflict (Haslam \& Tanimoune, 2016).

Finally, developing an effective administrative system allows for better policy implementation and increases the efficacy of revenue collection and redistribution. For decision-makers, the administrative system becomes one of the most important mechanisms for materializing the benefits of extractive activities. In the mining sector, a competent administrative system requires clarity concerning who makes the rules, who administers them, and who enforces them (Natural Resource Governance Institute, 2014).

\section{Method}

The analysis presented in this chapter relies on the systematic review of policy and technical documents, and local newspaper articles published between 2002 and 2018. An original database of newspaper articles was built using two sources with national coverage: El Comercio and El Universo. These sources were reviewed to identify major policy discussions and references to the policy instruments used to develop the mining sector in the period of interest. Indepth interviews with six policy elites (including ministers, vice-ministers, and presidential or ministerial advisors) were used to expand and validate the data obtained in the document review.

\section{Results}

This section presents the interdependent development of the oil and mining sectors, highlighting the effect of policy instrument choice in the former on 


\section{Paúl Cisneros}

the latter. The presentation of the data is chronological, and it is organized into two subsections. The first one presents the general development of the two sectors until 2006. The second subsection identifies the main policy instruments adopted to develop the metal mining sector across the political, economic, and administrative dimensions.

\section{Two interdependent policy sectors: oil and mining}

Since the 1980s, Ecuador has experienced a regressive pattern of specialization driven by the increase in oil extraction. Between 2000 and 2012, the weight of oil extraction in GDP and the percentage of the total income of the nonfinancial sector that originated from oil earnings increased (Mateo \& García, 2014; Caria \& Domínguez Martín, 2015). The economic crisis of 2008 and the consequent decrease of commodity prices reduced dependence in the 2008-2009 period, but there are indications that dependence grew after 2009. During the 2002 and 2012 period, the percentage of state revenue generated from oil exports increased from 22\% to 40\% (Mateo \& García, 2014).

The mining sector has trailed behind the oil sector in terms of its contribution to GDP, with less than $1 \%$ in the average during the same period. However, the development of these sectors has been deeply intertwined since 1999 because they were regarded as the main sources of revenue to maintain and expand social programs amid a major economic crisis. They were also seen as the main sources to serve the debt assumed through the bailout received from the International Monetary Fund and the World Bank in 2000 (Ruiz Acosta \& Cisneros, 2014).

The expansion of the oil frontier in the Amazon and the attraction of investments for exploration in the mining sector were two top priorities for the government of Gustavo Noboa (2000-2003). In this line, the government passed a package of open-market reforms for both sectors in the early 2000s. These reforms allowed the construction of a second oil pipeline by a consortium of private companies, which started in 2002 (the OCP or oleoducto de crudos pesados; see Figure 4.1).

In addition, the government passed an almost entirely new set of mining regulations in early 2001, creating "the most favorable conditions for the industry in Latin America." Despite the legal overhaul and the positive effect on the business climate, low mineral prices in the international markets, mergers, acquisitions, and changes of global corporate strategies delayed the advancement of the most important prospects (Velasco, 2002, 2003). Therefore, the bulk of gold production in Ecuador was carried out by small mining cooperatives (Velasco, 2002). In 2003, the World Bank reported that the Ministry of Energy and Mines (MEM) ${ }^{2}$ had abandoned overseeing and control in the mining sector because its limited administrative capacity was devoted to processing requests for new concessions and the development of the oil sector (Cisneros \& Christel, 2014). ${ }^{3}$

By 2004, dependency on oil had deepened due to rising prices in the international markets. Despite the high rate of economic growth experienced 
Pacific Ocean

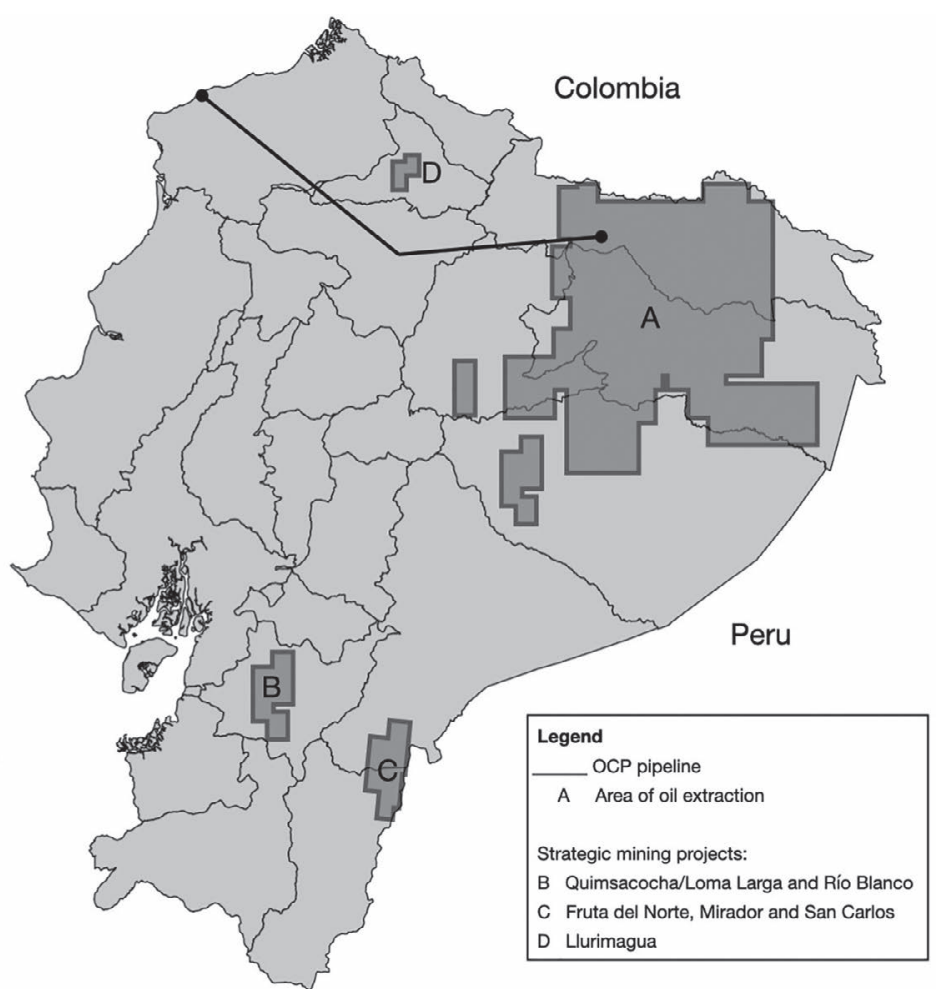

Figure 4.1 Location of oil extraction and metal mining projects in Ecuador

Source: Own elaboration

in 2004, the political landscape was deteriorating quickly. President Lucio Gutierrez (2003-2005) was ousted during social mobilizations after illegally replacing judges in the Supreme Court. Alfredo Palacio, who succeeded Gutierrez, announced a nationalistic turn in economic and oil policies to reverse the control that foreign private companies gained in the past half-decade in the production of oil and the capture of the extractive rent (Ruiz Acosta \& Iturralde, 2013). To this end, his government pushed for an amendment to the hydrocarbons law which mandated that the state should receive at least $50 \%$ of the benefits generated in the oil sector. The reform also raised the royalties paid by foreign oil companies on windfall profits (Anderson, 2009).

Palacio's plan to reform the oil sector that included a renegotiation of existing contracts with private foreign companies stalled growth of investments in the mining sector. One informant argues that "legal cases brought by the government against foreign oil companies and by foreign companies against Ecuador deterred foreign firms from investing in new exploration and development of mineral and fuel properties or from acquiring existing operations." 4 
Public protests against the exploration and development of large-scale projects increased during Palacio's government, further deterring investments (Anderson, 2007).

In 2005, numerous confrontations between activists and the military near mining sites led to the suspension of mining activities in Mirador and other large-scale projects. The government declared a halt to all mining operations for the sectoral authority to implement free, prior, and informed consultations with local communities and launched an initiative to reform the Mining Law (Ley de Minería). Palacio was unable to secure support from the National Congress to pass this reform before the end of his government.

\section{Policy goals and instruments}

With the election of Rafael Correa in 2006, the nationalistic policy agenda for the mining sector was revived. Correa was elected with support from Alianza País, a coalition of left-leaning groups and political figures who supported antiestablishment rhetoric. Correa forged alliances with former president Lucio Gutierrez's party to call for a referendum to install a Constituent Assembly. Alianza País and its allies won the elections for Assembly representatives, obtaining $70 \%$ of the seats. This result gave Correa and his political movement the power to shape the structure of the new constitution and the new regulations for oil and mining. The remainder of this subsection identifies some policy instruments used in the oil sector that were adopted in the mining sector to achieve political, economic, and administrative objectives and the outcomes of this adoption.

\section{The political dimension}

One of the main challenges for Correa's first government (2007-2011) was setting the conditions for developing a mining sector despite opposition from local communities and private companies (SENPLADES, 2007). Private companies, represented by the Mining Chamber of Ecuador (Cámara de Minería de Ecuador, CME), feared the consequences of the imminent increase of the tax burden, as occurred in the oil sector, where the state collected $99 \%$ of windfall profits. The CME warned that reintroducing royalty payments and taxes on windfall profits through a new sectoral law would discourage investments in mining (Cisneros, 2011).

On the other hand, civil society organizations demanded adequate controls over corporate behavior and open debate about the potential benefits and costs of advancing large-scale projects in certain areas. To reduce opposition from local communities, the MEM organized the so-called Mining Dialogue (Diálogo minero) in 2007. In the dialogue, companies and local communities were to define a strategy to advance several projects that had been stalled since 2005 (Ministerio de Energía y Minas, 2007). During the dialogue, civil society organizations exposed a series of administrative problems in the so-called 
strategic projects. Under pressure from the national anti-mining network or Coordinadora Nacional para la Defensa de la Vida y la Soberanía (National Coordinator for the Defense of Life and Sovereignty, CNDVS), the MEM formed tripartite technical commissions with representatives from the communities to investigate these allegations. The reports produced by the commissions documented systematic violations of administrative procedures in three projects (Mirador, Llurimagua, and Quimsacocha). Still, the government refrained from taking legal actions to avoid retaliation in international tribunals (Cisneros, 2011).

Civil society organizations decided to end their participation in the dialogue and turned to the Constituent Assembly to achieve bans on existing and new large-scale projects. Responding to this pressure, the Constituent Assembly passed the so-called Mining Mandate (Mandato Minero) or Mandate 4 in April 2008. With this decision, the Assembly ordered the government to implement a temporary moratorium on mining activities. It also ordered the suspension of exploration activities for six months or until a new Mining Law could be approved. Additionally, it mandated the government to revoke $80 \%$ of the country's mineral concessions and suspended the other 20\%. Mandate 4 extinguished 3,000 concessions where administrative requirements have not been met. Finally, the Mining Mandate halted approximately 1,200 pending requests for new concessions (Wacaster, 2010).

Correa's government used the implementation of the Mandate to generate consensus among the economic elites - the mining companies and the CME - regarding conditions for the development of the mining sector (Cisneros, 2011). To gain support for a new Mining Law, Correa eased regulations on social and environmental consultations, which legalized the continuation of the most advanced projects (Mirador, Fruta del Norte, and Quimsacocha; see Figure 4.1), even if they did not comply with Mandate 4 (see Murillo Martín \& Hurtado Caicedo, 2016).

Conflicts between mining companies and local communities increased with a partial implementation of Mandate 4. To manage these conflicts, the government adopted policy instruments used for decades in the oil industry. The government's approach relied on so-called community-relations teams, who paid community representatives to grant social licenses for companies (Narváez, 2004). An informant commented on how this approach affected the mining sector:

Despite the official announcement of a new approach to managing social conflicts, it [corporate-community relations] was seen as something that could be managed based on the experience developed in the oil sector. The government thought they could assemble a team to negotiate minor investments in the communities, somehow paid for by companies that were not yet making any money. Such community-relations teams managed intense conflicts in the oil sector, which drew permanent political attention from national authorities, and had money. However, these teams were not prepared to build long-term relationships that could last during 30 to 40 
years of mineral extraction.... [T] hey had no resources to offer. Now we see the effects of that lack of true consensus-building, not only in projects but for the development of the industry itself. ${ }^{5}$

The legacy of the policy instruments imported from the oil sector to deal with socio-environmental conflicts constrained the chances of Correa's successor, Lenin Moreno (2017-2021), to push the development of the mining sector forwards. By mid-2019, several strategic projects (Río Blanco, Loma Larga, and Llurimagua) were under heavy pressure by local communities and antimining organizations that demanded consultations in their jurisdictions. These demands were voiced in parallel to legal processes to stop mining projects due to a lack of compliance with social and environmental regulations. The town of Pacto near the capital city of Quito organized the first consultation in 2015, in reaction to the presence of a project owned by the National Mining Company (Empresa Nacional Minera, ENAMI-EP) (Ávila, 2015). Nearly 67\% of the population participated, and 97\% rejected ENAMI's project. In August 2018, the provincial court of Azuay ratified the suspension of the Río Blanco project in Azuay after determining the company had not carried out a process of free, prior, and informed consultation.

\section{The economic dimension}

In 2007, Correa's government introduced reforms that allocated 99\% of windfall profits from the oil sector to the government. Additionally, the government introduced a new contractual form by which the state pays private companies for specific services (exploration, extraction, and commercialization). The refusal of private companies to accept the terms laid out by the government prompted a reduction of the tax on windfall profits to $70 \%$ through the Law for Tax Equity (Ley de Equidad Tributaria) in mid-2008 (Mateo \& García, 2014). The legal actions launched by private companies dragged the country through a lengthy five-year process to renegotiate existing contracts (Wacaster, 2011).

Despite this setback to the implementation of the nationalistic approach to natural resource governance, the same policy instruments were adopted for the metal mining sector a year later. In a context of increasing social spending and high metal prices, the government announced the reintroduction of royalties for mining operations, and the adoption of windfall taxes despite opposition by the mining guild. As one informant commented:

At the time, the government did not understand the nature and the magnitude of investments required in the mining sector before sales produce profits. The idea they had that granting a mining concession means that mineral production starts soon after, as it more or less happens with oil, had people believing that the most advanced projects (Mirador and Fruta del Norte) would start paying royalties in a couple of years. That is not how the mining industry works. Companies have to invest large amounts of money, 
which has to be recovered within the first years of production, and only from then on is there a profit that could be taxed by the state. ${ }^{6}$

This decision stalled the flow of new investments to the metal mining sector between 2008 and 2010. Moreover, the owners of the most advanced projects sold part or the entirety of their assets in the country. In 2008, Aurelian Resources sold Fruta del Norte to Kinross Gold, and Corriente Resources sold Mirador to a conglomerate of Chinese mining companies. Policy actors fully grasped the consequences of the decisions made regarding the tax regime when Kinross Gold, owner of the Fruta del Norte project, announced it would sell the majority of its interests in mid-2013. At the time, Kinross Gold CEO said, "we have been at the negotiating table for two years ... and sometimes the best deal is the one you don't sign, and we believe that's the case here" (El Telégrafo, 2013). The exit of Kinross from one of the most significant gold discoveries of the decade marked

the moment when government authorities perceived mining as fundamentally different from oil. It also made it clear that other countries in the region were still operating in a completely different scenario, one similar to the regulations dismantled in 2008 by the new constitution. Moreover, for some people in the government, the limits of the nationalistic project became apparent, and more so considering the recent exponential growth of mining in Peru and Chile. ${ }^{7}$

Between 2007 and 2012, the government allocated a budget to develop competitive advantages that would serve to attract investments to the mining sector. It invested nearly US $\$ 16$ billion or $4 \%$ of the annual GDP on infrastructure for the strategic sectors. ${ }^{8}$ Among these, investments in renewable energy (hydropower) and roads were the most considerable, receiving US $\$ 4.5$ billion and US $\$ 6$ billion, respectively (Caria \& Domínguez Martín, 2015). According to the objectives laid out in the 2009-2013 National Development Plan (Plan Nacional para el Buen Vivir), the remainder would provide cheap energy to reduce the reliance of the economy on the primary sector. Caria and Domínguez Martín show that between 2009 and 2014, the Ecuadorian economy did not show signs of diversification or improved systemic productivity (Caria \& Domínguez Martín, 2015, pp. 53-54).

On the other hand, when the government refrained from adopting instruments from the oil sector, it produced some positive outcomes for the development of the mining sector. This is apparent in the case of redistributing revenue to local communities. Whereas in the oil sector this redistribution was largely in the hands of oil companies, Correa's government made use of various mechanisms to boost public investment in mining regions. In 2010, it reformed the General Regulations of the Mining Law (Reglamento General de la Ley de Minería) to define the percentage of the royalties to be paid by mining companies and the criteria for their allocation to the local governments 
(municipalities and parishes) where extraction takes place. The government also created the public company Strategic Ecuador (Ecuador Estratégico, EE) in 2011, under the Coordinating Ministry for Strategic Sectors (Ministerio Coordinador de los Sectores Estratégicos, MICSE). ${ }^{9}$ EE's mission was to invest resources from royalty payments as part of local development plans or through programs and projects defined at the national level. These decisions reduced opposition to mining in certain areas, in particular near the Fruta del Norte and Mirador projects. ${ }^{10}$

Regarding the taxation of private mining companies, the policies adopted by the government diverged from those in use in the oil sector. Not all mining companies had made significant discoveries that allowed them the cash flow to commit to paying anticipated royalties to the government. Therefore, the mining guild continued lobbying to reform the tax regime. By the government's initiative, in late 2016, the National Assembly approved the Ley de Plusvalía (Law on Capital Gains) that contained a mechanism to defer tax payments for four years after mining companies recovered their capital investments. The mining minister expected these reforms to bring nearly US $\$ 4.6$ billion until 2021 to help the Río Blanco, Mirador, and Fruta del Norte begin with production. ${ }^{11}$ Aided by the influx of new investments, the latter two projects started production in 2019.

\section{The administrative dimension}

Despite the clear policy objective of extracting metals to increase state revenue and social spending, the required changes in administration came slowly. To begin with the development of a new institutional architecture for the strategic sectors, Correa's government split the MEM into two agencies in 2007. One agency received the competencies on electricity and renewable energy (the Ministerio de Electricidad y Energías Renovables, Ministry for Electricity and Renewable Energies), while the other became the Ministry of Mines and Petroleum (Ministerio de Minas y Petróleos, MMP). Within the latter, the mining sector was headed by the Vice Ministry of Mines (Viceministerio de Minas). Still, the administrative reform of the mining sector faced the challenge of structuring a competent administrative system. At the time, "the mining cadastre, which is arguably the administrative heart of the mining industry, existed in an Excel spreadsheet without any proper securities or control". ${ }^{12}$ To make matters worse, the intervention of the Constituent Assembly over existing concessions delayed initiatives to improve the administrative capacity until 2009.

The process of institutional development resumed when the Legislative Commission, ${ }^{13}$ where Alianza País still held the majority, approved the Mining Law in early 2009. The Law defines the structure of the mining sector with the MMP as a sectoral authority, and two ascribed agencies, one for regulation (ARCOM), and one for geological research (INIGEMM), and a dependent national mining company, ENAMI-EP. In this context, the government changed the name of the MMP to the Ministry of Nonrenewable Natural 
Resources (Ministerio de Recursos Naturales no Renovables, MRNNR). This organization maintained the responsibility for the exploitation of nonrenewable natural resources, policy management, and research and development. ARCOM received the task of updating and managing the mining cadastre, while the Vice Ministry of Mines held the responsibility of designing sectoral policy.

Before the end of the year, the Vice Ministry of Mines issued new environmental regulations, as well as rules for small and artisanal mining, and the General Regulations of the Mining Law. However, by the end of the year, there was still uncertainty among private companies regarding the general conditions for the administrative management of mining in Ecuador. Concerns were related to how strictly the new legislation would be applied, and the extent to which foreign investment would be affected by the new rules (Wacaster, 2011, p. 1).

One of the critical amendments related to demands made by private companies and the CME was the creation of a specialized and competent authority, a proper ministry of mines. Some key actors from within the government also supported this idea:

We at the Coordinating Ministry of Strategic Sectors (MICSE) were convinced that it was necessary to separate mining and oil. Due to the nature of the oil sector, you cannot divide your attention between the two. . . One of the main reasons to demand a different institution is that in practice, the minister will always prioritize oil due to its current economic importance. .. Even within the MRNNR, there was support for the break-up. ${ }^{14}$

In 2015, Correa admitted that developing the mining sector required a specialized ministry. He stated that "currently, as a Vice Ministry within the Ministry of Nonrenewable Resources, mining has been absorbed by oil. . . . There has not been enough support or resources for the mining sector" (El Telégrafo, 2015). Therefore, he created the Ministry of Mines in 2015. Now that mobilizing authority resources had pushed the mining sector to the forefront, the challenge was to ensure that treasury resources followed. However, due to the economic crisis caused by the reduction in oil prices since 2014 ,

the Ministry of Finance assigned only half the money and resources required for the new Ministry of Mines, and ARCOM, which is a regulatory agency, retained the most important piece of mining policy: the management of the mining cadastre. This decision split policy authority in two. ${ }^{15}$

Another critical piece of the institutional architecture for the mining sector mandated by the 2009 law was the creation of a state-owned company. This organizational model was adopted from the oil sector even though the two state-owned oil companies had performed poorly in previous years. On December 31, 2009, the government created ENAMI-EP with preferential 
access to mineral resources to be developed in association with other public companies, and only as an exception with private partners (Wacaster, 2011, p. 1). Therefore, the effect of the creation of ENAMI-EP over the operations of private mining companies was unclear. Several informants acknowledge that ENAMI-EP emerged mostly from the dominant ideas in the oil sector:

ENAMI-EP . . . is Correa's pipedream. His nationalist ideology made him emulate the system we had in place for hydrocarbons. In principle, it makes sense that operating directly through a public company, the state could make more money, as CODELCO in Chile does. However, in the mining world, profitable public companies are rare. The private sector drives the mining industry because the risk of investing and not finding anything is high, and because of the long-term horizons of extraction that are incompatible with most political horizons. Moreover, having a public company that assumes risks in exploration is incompatible with our system of control of public resources, because not generating revenue is punished by the Comptroller General's Office, it is just not a viable option. ${ }^{16}$

Between 2010 and 2019, ENAMI-EP did not produce a single project or partnership with a clear outcome for large-scale projects.

The process of granting new concessions had also been influenced by policy ideas and instruments used in the oil sector:

Both the state and society were used to the so-called oil rounds. It was what we knew how to do. Therefore, the local professionals who are just learning about mining steered us (the MEM) towards the mechanisms used in the oil sector. We decided to hire a company with global experience to look at the factors promoting competitiveness in the region. They suggested we adopt a Swiss challenge to grant concessions. Help from outside actors was key to create something viable. ${ }^{17}$

The adoption of this mechanism produced some positive outcomes for the mining sector. With this novel instrument, the government granted a total of 235 new concessions, and between 2016 and 2017, Ecuador received roughly US\$1.153 billion in investment.

The economic crisis of late 2015 and early 2016, and the austerity measures deployed by President Moreno between 2017 and 2019, slowed down the consolidation of the institutional architecture described previously. ENAMIEP's budget was slashed. As one informant notices: "It was hard to justify the existence of a national company that at some point had made some progress towards working with small mining cooperatives but had not developed major projects yet." 18

Additionally, ENAMI was not able to manage the social conflicts created by private companies in previous years (Avci, 2015). The conflicts in the region of Intag dragged on and affected a copper-molybdenum project known as 
Llurimagua, where ENAMI-EP partnered with CODELCO in 2011. The conflict escalated in September 2014 when the government released a hastily completed 1,000-page environmental impact assessment for public review (Wacaster, 2017, p. 2), which, according to local organizations, did not comply with existing regulations for environmental assessments. The Office of the Comptroller General (Contraloría General del Estado) verified these failures in a report released in 2019 (Redacción La Hora.EC, 2019), and the project came to a halt.

As part of the austerity measures launched in 2017, President Moreno announced a merger between the ministries of Electricity, Mines, and Hydrocarbons. The argument presented by the government for this decision was that creating a strong super-ministry (the Ministry of Nonrenewable Resources) would increase the government's capability for pushing the new long-term policies designed for the energy, mining, and oil sectors. With this new architecture in place by early 2018, the sectoral authority of the mining sector was again the Vice Ministry of Mines, under the Ministry of Energy and Nonrenewable Resources. The president appointed an expert in hydrocarbons as head of this new Vice Ministry. Although this re-organization went against the process of learning experienced between 2008 and 2015 and historical demand of the mining guild for having the support of a specialized authority, the biggest concern for mining companies at the time related to the proliferation of local consultations to stop large-scale projects as discussed earlier.

\section{Concluding remarks}

The literature on the resource curse shows several adverse effects or negative feedbacks that occur with the development of the extractive sectors over the rest of the economy. The Dutch disease and middle-income traps are some of these adverse effects. More recent discussions on the extractive imperative propose that the growth of extractive activities generate conditions for their continuous expansion. However, scholars have said less about the negative feedbacks caused by one extractive sector on the development of another. The aim of this chapter was to expand the current discussion of the potential negative effects of resource dependence on institutional development.

To this end, this chapter studied some negative feedbacks created by the dynamics of the oil sector on the development of the mining sector in Ecuador along political, economic, and administrative dimensions. The empirical findings show that, between 2006 and 2019, the adoption of policy instruments used in the oil sector constrained the development of the mining sector because they were inconsistent with the objective conditions existing in the latter.

Fighting this form of cross-contamination between policy sectors is a challenging task. Policy-makers, as well as other actors, make sense of the world through existing policy ideas and the instruments they know best. Often, as shown in this chapter, changing existing ideas on how the mining sector should develop is the greatest barrier for choosing adequate instruments to achieve 
desired goals. However, this problem may be harder to tackle in countries like Ecuador, where decision-making is so concentrated in the figure of the president, and a pluralistic selection of policy instruments is difficult to achieve. Countries where industry actors and civil society organizations have greater legitimacy in the policymaking process may see reduced negative effects of oil dependence on the development mining sector.

Findings also show that learning is still possible under the extractive imperative. Several policy instruments were chosen that departed from what had been previously used in the oil sector and helped the government achieve some policy goals. Future research should look comparatively at the performance of policy designs employed to develop the mining sector in countries with greater and milder economic dependence on natural resources. Pursuing this line of inquiry will help scholars gain a better understanding of the political, economic, and administrative conditions that influence the adoption of policy ideas and instruments. This would add another layer of complexity to the phenomenon of the resource curse, one that uncovers important institutional implications.

\section{Notes}

1 Interview with former president of the Mining Chamber of Ecuador, Quito, August 20, 2020.

2 At the time, the Ministry of Energy and Mines (Ministerio de Energía y Minas, MEM) was the national authority for oil and mining sectors. The Undersecretary of Mines (Subsecretaría de Minas) was the national authority for the mining sector.

3 Since 1997, when environmental decentralization was adopted, the MEM was also in charge of approving environmental impact assessments, coordinating with the Ministry of the Environment, processing annual follow-up environmental reports, enforcing environmental regulations, and overseeing negotiations between mining companies and local communities.

4 Interview with former president of the Mining Chamber of Ecuador, Quito, August 20, 2020.

5 Interview with former Undersecretary of Mines, Quito, February 7, 2019.

6 Interview with former Vice Minister of Mines, February 15, Quito, 2019.

7 Interview with former Undersecretary of Mines, Quito, February 7, 2019.

8 The 2008 constitution defines the strategic sectors as those that decisively influence the economic, social, political, and environmental life of the country. Among others, the list of strategic sectors includes energy and nonrenewable natural resources.

9 The democratic reform of the state launched by Correa's government in 2007 defined a level of intersectoral coordination headed by Coordinating Ministries, of which seven were created. These ministries presided over the so-called sectoral councils. The Coordinating Ministry for Strategic Sectors (Ministerio Coordinador de los Sectores Estratégicos, MICSE) presided the sectoral council for strategic sectors that by 2017 included the Ministry of Hydrocarbons (Ministerio de Hidrocarburos), the Ministry of Mines (Ministerio de Minas), the Ministry of the Environment (Ministerio del Ambiente), and the Secretariat for Water (Secretaría del Agua). MICSE was suppressed in 2017 by president Moreno within the implementation of austerity measures needed to access loans from the World Bank and other international lenders.

10 It is worth noting that the government also increased the criminalization of protest as a means to contain opposition from organized civil society (see FIDH, 2015). 
11 See Redaccción Plan V (2017). In February 2018 the Law of Capital Gains was repealed in a national referendum.

12 Interview with former Undersecretary of Mines, Quito, February 7, 2019.

13 When the period of the Constituent Assembly ended in July 2008, representatives were appointed to the Legislative Commission, which was later replaced by the National Assembly in 2009.

14 Interview with former Vice Minister of Mines, Quito, February 15, 2019.

15 Interview with former Vice Minister of Mines, Quito, February 15, 2019.

16 Interview with former Vice Minister of Mines, Quito, February 15, 2019.

17 Interview with former Undersecretary of Mines, Quito, February 2019.

18 Interview with former president of the Mining Chamber of Ecuador, Quito, August 20, 2020.

\section{References}

Acosta, M. R., \& Iturralde, P. (2013). La alquimia de la riqueza. Estado, petróleo y patrón de acumulación en Ecuador. Centro de Derechos Económicos y Sociales.

Anderson, S. T. (2007). The mineral industry of Ecuador in 2005. United States Geological Service. https://s3-us-west-2.amazonaws.com/prd-wret/assets/palladium/production/ mineral-pubs/country/2005/ecmyb05.pdf

Anderson, S. T. (2009). The Mineral Industry of Ecuador in 2006. United States Geological Service. https://s3-us-west-2.amazonaws.com/prd-wret/assets/palladium/production/ mineral-pubs/country/2006/myb3-2006-ec.pdf

Arsel, M., Hogenboom, B., \& Pellegrini, L. (2016a). The extractive imperative in Latin America. The Extractive Industries and Society, 3(4), 880-887. https://doi.org/10.1016/j. exis.2016.10.014

Arsel, M., Hogenboom, B., \& Pellegrini, L. (2016b). The extractive imperative and the boom in environmental conflicts at the end of the progressive cycle in Latin America. The Extractive Industries and Society, 3(4), 877-879. https://doi.org/10.1016/j.exis.2016.10.013

Arzeki, R., Gylfason, T., \& Sy, A. (Eds.). (2011). Beyond the curse. IMF. notendur.hi.is/ gylfason/Beyond_the_Curse_Arezki_Gylfason_Sy.pdf

Auty, R. M. (1993). Sustaining development in mineral economies: The resource curse thesis. Routledge.

Avci, D. (2015). Mining conflicts and transformative politics: A comparison of Intag (Ecuador) and Mount Ida (Turkey) environmental struggles. Geoforum, 84, 316-325. https:// doi.org/10.1016/j.geoforum.2015.07.013

Ávila, T. (2015, April 1). Yo soy de Pacto y no quiero minería. Plan V. www.planv.com.ec/ideas/ ideas/yo-soy-pacto-y-no-quiero-mineria

Baumgartner, F. R., \& Jones, B. D. (1991). Agenda dynamics and policy subsystems. The Journal of Politics, 53(4), 1044-1074. https://doi.org/10.2307/2131866

Bebbington, A., Abdulai, A.-G., Humphreys, D., Hinfelaar, M., \& Sanborn, C. (2018). Governing extractive industries. Oxford University Press.

Bebbington, A., Fash, B., \& Rogan, J. (2019). Socio-environmental conflict, political settlements, and mining governance: A cross-border comparison, El Salvador, and Honduras. Latin American Perspectives, 46(2), 84-106. https://doi.org/10.1177\%2F0094582X18813567

Caria, S., \& Domínguez Martín, R. (2015). Estructura productiva primario-exportadora y Buen Vivir en Ecuador, 2009-2014. Revista Internacional de Cooperación y Desarrollo, 2(1), 37-64. hdl.handle.net/10902/9782

Cisneros, P. (2011). ¿Cómo se construye la sustentabilidad ambiental?: Análisis de experiencias conflictivas de la industria minera en el Ecuador [Tesis doctoral]. FLACSO. hdl.handle. net/10469/5707 
Cisneros, P. (2017). ¿Por qué no avanza la megaminería en el Ecuador? Un análisis de las disputas por la política pública en Cuenca. In L. Bottar \& M. Solá Álvarez (Eds.), Agua y megaproyectos en América Latina (pp. 57-84). Ediciones UNGS.

Cisneros, P., \& Christel, L. (2014). The democracy deficit of corporate social responsibility in post-neoliberal times: An analysis of the Argentinian and Ecuadorian experiences. Journal of Cleaner Production, 84(1), 174-182. https://doi.org/10.1016/j.jclepro.2014.03.032

El Telégrafo. (2013, June 11). Kinross Gold abandons Ecuadors largest untapped gold deposit. www.eltelegrafo.com.ec/noticias/english/1/kinross-gold-abandons-ecuador-s-largestuntapped-gold-deposit

El Telégrafo. (2015, February 13). Nuevo Ministerio de Minería se crea por Decreto Ejecutivo. www.eltelegrafo.com.ec/noticias/politica/3/nuevo-ministerio-de-minas-se-crea-pordecreto-ejecutivo

FIDH. (2015). Criminalización de la protesta social frente a proyectos extractivos en Ecuador. Misión Internacional de Investigación. INREDH/FIDH. www.fidh.org/IMG/pdf/equateur666espagn2015hd_1_.pdf

Gylfason, T. (2006). Natural resources and economic growth from dependence to diversification. In H. Broadman, T. Paas, \& P. J. Welfens (Eds.), Economic liberalization and policy integration: Options for Eastern Europe and Russia (pp. 201-231). Springer-Verlag. https:// doi.org/10.1007/3-540-31183-1

Haslam, P. A., \& Tanimoune, N. A. (2016). The Determinants of social conflict in the Latin American mining sector: New Evidence with Quantitative Data. World Development, 78, 401-419. https://doi.org/10.1016/j.worlddev.2015.10.020

Howlett, M., \& Cashore, B. (2009). The dependent variable problem in the study of policy change: Understanding policy change as a methodological problem. Journal of Comparative Policy Analysis: Research and Practice, 11(1), 33-46. https://doi.org/10.1080/13876980802648144

Lascoumes, P., \& Le Gales, P. (2007). Introduction: Understanding public policy through its instruments - from the nature of instruments to the sociology of public policy instrumentation. Governance, 20(1), 1-21. https://doi.org/10.1111/j.1468-0491.2007.00342.x

Mateo, J. P., \& García, S. (2014). El sector petrolero en Ecuador. 2000-2010. Problemas del desarrollo, 45(177), 113-139. www.scielo.org.mx/pdf/prode/v45n177/v45n177a6.pdf

Mayorga Alba, E. (2009). Extractive industries value chain: A comprehensive integrated approach to developing extractive industries. Africa Working Paper Series No. 125. World Bank. hdl.handle.net/10986/18400

Ministerio de Energía y Minas. (2007). In El ABC de la minería en el Ecuador. Ministerio de Energía y Minas. es.slideshare.net/CDESecuador/abc-de-la-mineria

Mukhtarov, F., \& Daniell, K. A. (2016). Transfer, diffusion, adaptation, and translation of water policy models. In K. Conca \& E. Weinthal (Eds.), The Oxford handbook of water politics and policy (pp. 1-29). https://doi.org/10.1093/oxfordhb/9780199335084.013.30

Murillo Martín, D., \& Hurtado Caicedo, F. (2016). Incumplimiento del mandato minero en proyectos mineros del sur de Ecuador. CEDHU. repositorio.dpe.gob.ec/bitstream/39000/2537/1/ PE-029-DPE-2020.pdf

Narváez, I. (2004). Metodología de relacionamiento comuniario no ortodoxas: análisis politico para abordarlas. In G. Fontaine (Ed.), Petróleo y desarrollo sostenible en Ecuador: Las apuestas (pp. 75-90). FLACSO Ecuador.

Natural Resource Governance Institute. (2014). Natural resource charter (2nd ed.). NRGI. resourcegovernance.org/sites/default/files/NRCJ1193_natural_resource_charter_19.6.14.pdf

Nohrstedt, D. (2005). External shocks and policy change: Three-mile island and Swedish nuclear energy policy. Journal of European Public Policy, 12(6), 1041-1059. https://doi. org/10.1080/13501760500270729 
Orihuela, J. C., \& Paredes, M. (2017). Fragmented layering: Building a green state for mining in Peru. In E. Dargent, J. C. Orihuela, M. Paredes, \& M. E. Ulfe (Eds.), Resource booms and institutional pathways (pp. 97-118). Palgrave. https://doi.org/10.1007/978-3-319-53532-6

Ponce Muriel, Á. (2012). ¿Cuál locomotora?: El desalentador panorama de la minería en Colombia. Random House Mondadori.

Radaelli, C. M. (1995). The role of knowledge in the policy process. Journal of European Public Policy, 2(2), 159-183. https://doi.org/10.1080/13501769508406981

Redacción La Hora.EC. (2019, January 28). Proyecto minero Llurimagua bajo la lupa de la Contraloría. OCMAL. www.ocmal.org/proyecto-minero-llurimagua-bajo-la-lupa-de-la-contraloria/

Redacción Plan V. (2017, October 17). Los agujeros del proyecto minero Fruta del Norte. Plan V. www.planv.com.ec/historias/sociedad/agujeros-del-proyecto-minero-fruta-del-norte

Ross, M. L. (2015). What have we learned about the resource curse? Annual Review of Political Science, 18, 239-259. https://doi.org/10.1146/annurev-polisci-052213-040359

Ruiz Acosta, M. A., \& Cisneros, P. (2014). Crisis de hegemonía y recomposición del pacto estatal ecuatoriano, 1990-2008. In R. Echavarría (Ed.), Pugna de poderes, crisis orgánica e independencia judicial (pp. 61-87). Instituto de Altos Estudios Nacionales.

Schneider, A., \& Ingram, H. (1990). Behavioral assumptions of policy tools. The Journal of Politics, 52(2), 510-529. https://doi.org/10.2307/2131904

SENPLADES. (2007). Plan Nacional de Desarrollo 2007-2010. Gobierno Nacional de la República del Ecuador. www.planificacion.gob.ec/wp-content/uploads/downloads/2013/09/Plan-Nacional-Desarrollo-2007-2010.pdf

Velasco, P. (2002). The mineral industry of Ecuador in 2000. United States Geological Service. s3-us-west-2.amazonaws.com/prd-wret/assets/palladium/production/mineral-pubs/ country/2002/ecmyb02.pdf

Velasco, P. (2003). The mineral industry of Ecuador in 2001. United States Geological Service. https://s3-us-west-2.amazonaws.com/prd-wret/assets/palladium/production/mineralpubs/country/2000/9511000.pdf

Wacaster, S. (2010). The mineral industry of Ecuador in 2008. United States Geological Service. https://s3-us-west-2.amazonaws.com/prd-wret/assets/palladium/production/mineralpubs/country/2008/myb3-2008-ec.pdf

Wacaster, S. (2011). The mineral industry of Ecuador in 2009. United States Geological Service. https://s3-us-west-2.amazonaws.com/prd-wret/assets/palladium/production/mineralpubs/country/2009/myb3-2009-ec.pdf

Wacaster, S. (2017). The mineral industry of Ecuador in 2014. United States Geological Service. https://s3-us-west-2.amazonaws.com/prd-wret/assets/palladium/production/mineralpubs/country/2014/myb3-2014-ec.pdf

Weible, C. M., \& Sabatier, P. A. (2009). Coalitions, science, and belief change: Comparing adversarial and collaborative policy subsystems. Policy Studies Journal, 37(2), 195-212. https://doi.org/10.1111/j.1541-0072.2009.00310.x

Weyland, K. (2006). Bounded rationality and policy diffusion: Social sector reform in Latin America. Princeton University Press. 